\title{
An Analysis of Conspiracy Beliefs of Covid-19 Vaccination in Ghana
}

\author{
Gloria Ahima Baffoe, Naa Korkor Leeyoo Watson Nortey \\ Department of Communication and Media studies, University of Education, Winneba, Ghana \\ Email: botcheygloria294@gmail.com, leyoowatson@gmail.com
}

How to cite this paper: Baffoe, G. A., \& Nortey, N. K. L. W. (2021). An Analysis of Conspiracy Beliefs of Covid-19 Vaccination in Ghana. Advances in Journalism and Communication, 9, 196-208.

https://doi.org/10.4236/ajc.2021.94014

Received: November 8, 2021

Accepted: December 25, 2021

Published: December 28, 2021

Copyright $\odot 2021$ by author(s) and Scientific Research Publishing Inc. This work is licensed under the Creative Commons Attribution International License (CC BY 4.0).

http://creativecommons.org/licenses/by/4.0/

\begin{abstract}
This is a survey which researched into the perspectives of Ghanaians about conspiracy beliefs of COVID-19 vaccination in Ghana. Most Ghanaians who believe in science and in the strength of COVID-19 vaccine in the country to help stop the spread of the corona virus disease have been vaccinated and are willing to convince others to be vaccinated. However, others hold varied views concerning the existence of the virus itself and the extreme adverse effect of the vaccine should they take it. Like some vaccines that have been used to curtail some ailments, the COVID-19 vaccine has been received with mixed feelings. The result of the study reveals that conspiracy beliefs of COVID-19 vaccination are not highly prevalent in Ghana.
\end{abstract}

\section{Keywords}

Vaccination, COVID-19, Conspiracy, Beliefs

\section{Introduction}

The Coronavirus disease 2019 (COVID-19) is an infectious disease caused by coronaviruses, specifically, severe acute respiratory syndrome coronavirus 2 (SARS-CoV-2) (Coronaviridae Study Group of the International Committee on Taxonomy of Viruses, 2020; Aylward \& Liang, 2020). The virus was identified and reported from Wuhan City of China in December, 2019 (Du Toit, 2020) COVID-19 is transmitted from person to person through small droplets from the nose or mouth, which are expelled when a person with COVID-19 coughs, sneezes, or speaks via contact with fomites (Aylward \& Liang, 2020). The SARSCoV-2 which is highly contagious, spread globally in a short period of time, and was declared a global pandemic by the World Health Organization on March 11, 2020 (Lone \& Ahmad, 2020).

In Ghana, the first two cases of COVID-19 infection were recorded on 12th 
March, 2020. In a frantic effort to control the spread of the infection which had already been reported in three regions of Ghana: The Greater Accra, Ashanti, and Upper West Regions, the President of Ghana imposed a partial lockdown from 01:00 GMT beginning 30 $0^{\text {th }}$ March 2020, for 21 days in pursuant to the powers granted him under the Imposition of Restrictions Act, 2020 (Act 1012). On the day of the announcement, there were already 141 reported confirmed COVID-19 cases with 5 fatalities. Citizens were only permitted to leave homes for essential items such as food, medicine, water, pay their utility bills, as well as visit the hospital, pharmacies, or banks, among others. The government of Ghana outlined five objectives to address the likely effects of the COVID-19 pandemic in Ghana. These were 1) limit and stop the importation of the virus; 2) contain its spread; 3 ) provide adequate care for the sick; 4) limit the impact the virus on social and economic life; and 5) expand domestic production capability to strengthen self-reliance (http://www.ghananewsagency.org/20 $20^{\text {th }}$ April, 2020 cited in Afriyie et al., 2020).

Fast forward, 23rd June, 2020, marked exactly 100 days since Ghana confirmed the first two reported cases of COVID-19. As of that time, Ghana's case count stood 14,568 out of which 10,907 persons had recovered and 95 declared officially dead (http://www.myjoyonline.com/ $23^{\text {rd }}$ June, 2020) and as of the time of engaging in this study, Ghana's case count stood 127,482 out of which 123,238 persons had recovered and 1156 declared officially dead. The novel corona virus has indeed had dire consequences on residents of Ghana and many who have lost their livelihoods prayed the government of Ghana to enforce all measures put in place as well as look for vaccines as soon as they are developed to help curtail the spread of the disease in Ghana.

\section{Statement of the Problem}

Vaccines are effective tools that protect health and prevent diseases. It has been established by scientists that vaccination reduces the mortality rate and gravity of disease caused by SARS-CoV-2 (Abu-Raddad, Chemaitelly, \& Butt, 2021). When people are vaccinated against Coronavirus disease, the virus can not transmit as easily as possible from person to person, and the community is less likely to contract COVID-19 which is called "community immunity" or "herd immunity" (Aschwanden, 2020). It means, the more people are vaccinated, the lesser the chance of COVID-19 spread. High vaccination rates protect vulnerable population such as infants, old age people, pregnant women, first-line health workers and people of all ages with compromised immune systems, who are not fully vaccinated yet (Polack et al., 2020).

Since the COVID-19 pandemic continues to erupt, and morbidity and mortality figures continue to soar globally, the seriousness of this issue has made it imperative for the swift and unprecedented development of COVID-19 vaccine to ensure people get access to affordable, safe, and efficacious vaccine. Many efforts have been directed towards the development of the vaccines against COVID-19 
to avert the pandemic and most of the developing vaccine candidates have been using the S-protein of SARS-CoV-2 (Dhama et al., 2020). However, according to data released by World Health Organization (WHO), as of 5 August 2021, only $15.1 \%$ of the world's population had been fully vaccinated. In many countries, boycotting and rejecting COVID-19 vaccines and vaccine hesitancy remain widespread (Chou \& Budenz, 2020; Dror et al., 2020; Thigpen \& Funk, 2020; Troiano \& Nardi, 2021).

Ghana became the first country in the world to receive about 600,000 COVAX vaccines, AstraZeneca/Oxford vaccine, licensed to the Serum Institution of India to be used in the country. The president of Ghana, members of council of state, clergy, senior media practitioners and a host of other dignitaries publicly took their first jab of the vaccine to convince and assure Ghanaians about the safety and efficacy of the vaccine. This was to debunk conspiracy theories about the misinformation of COVID-19 that were propagating fast, especially through social media (Gruzd \& Mai, 2020; Ferrara, 2020) that had also got some Ghanaians already wading into the conversation on social media. Conspiracy theories are omnipresent among members of modern and traditional societies (West \& Sanders, 2003). Most people in the world believe in conspiracy theories. In 2004, $49 \%$ of New York City inhabitants believed the U.S. government to be complicit in the 9/11 terrorist attacks (Sunstein \& Vermeule, 2009). In addition, in a nationally representative sample of the U.S. population, $37 \%$ answered "agree" to the following statement: "the Food and Drug Administration is deliberately preventing the public from getting natural cures for cancer and other diseases because of pressure from drug companies." Another 31\% answered "neither agree nor disagree," and only $32 \%$ dissented with this statement (Oliver \& Wood, 2014a).

COVID-19 is not the first disease which brings along conspiracy theories (Oliver \& Wood, 2014b). Vaccines are a frequent topic (Jolley \& Douglas, 2014; Kata, 2012), and such theories have also been shown to be problematic in AIDS prevention (Herek \& Glunt, 1991; Herek \& Capitanio, 1994), or recently in the prevention of the spread of Zika (Klofstad, Uscinski, Connolly, \& West, 2019) and Ebola (Vinck, Pham, Bindu, Bedford, \& Nilles, 2019). Vaccine apprehension has been linked to religious values, personal beliefs, and safety issues based on widespread misconceptions, such as the connection between vaccines and autism, brain injury, and other disorders, according to various reports (McKee \& Bohannon, 2016). At the heart of the anti-vaccine conspiracy movement lays the argument that large pharmaceutical companies and governments are covering up information about vaccines to meet their own sinister objectives (Jolly \& Douglas, 2014). According to the most popular theories, pharmaceutical companies stand to make such healthy gains from vaccines that they bribe researchers to fake their data, cover up substantiation of the dangerous side effects of vaccines, and inflate statistics on vaccine efficacity (Kata, 2012; Offit, 2010). Along the same vein, Kata (2010) posits that anti-vaccine conspiracy theories present an attempt to explain away overwhelming scientific evidence that vaccines are 
effective, safe, and necessary. Another potential block to the success of COVID-19 vaccinations is a negative public opinion of the vaccine. A June 2020 survey found that $71.5 \%$ of people would be very or somewhat likely to take a COVID-19 vaccine, leaving almost a third less accepting of the vaccine. However, this could have a serious impact on the vaccine's implicit efficacity at controlling the spread of COVID-19 If significant portions of the population were to reject the vaccine. In Russia, for example, less than $55 \%$ of those surveyed would accept the vaccine (Moore, 2021). Past studies found that many people are rejecting scientific facts due to conspiracy theories "criminalizing" medicine and medication (Douglas et al., 2017). People continue to have doubts about vaccine safety and efficacy, including the durability of COVID-19 defense, as many cases of reinfection have been recorded (Reuters, 2021; Chen et al., 2020). Vaccine hesitancy and resistance are major issues around the world, causing the World Health Organization (WHO) to list them among the top ten health risks for 2019 (Geoghegan, O'Callaghan, \& Pa, 2020).

In Ghana few researches has been conducted on Covid-19. For instance, Kenu Frimpong and Koram (2020) looked at Ghana's response to the Covid-19 pandemic and concluded that a clear social distancing and personal hygiene measures should be enforced in the workplace with well-defined batch system working groups that are separated from each other to help curb the spread. Asante and Mills (2020) also researched into Socio-Economic Impact of COVID-19 Pandemic in Market places in Urban Ghana. Their findings revealed that the presence of Covid-19 has the huge impact of limiting access to affordable food in Ghana and other African countries. Lamptey et al. (2021) also looked at the Potential Acceptance and Determinants of COVID-19 vaccines in Ghana. Their study which measured people's intentions of accepting the vaccine should they be available revealed that Ghanaians had the intention of accepting the vaccine. However, the researchers were of the view that the real intention might differ when the vaccine is available as intention varies over time and in the context of a dynamic society. They also stated that they were unable to explore the motivation behind the acceptance or barriers behind the hesitancy of the COVID-19 vaccine. Now the vaccine is available in Ghana, but to determine whether Ghanaians were ready to take the vaccine or not was the puzzle this research sought to unravel. Based on this, this study sought to explore the perspectives of some Ghanaians after the introduction of COVID-19 vaccines in Ghana and examined whether conspiracy beliefs about the vaccine would prevent Ghanaians from taking the COVID-19 vaccine or not.

\section{Objective}

1) To explore the prevalence of conspiracy beliefs in Ghana after the preface of the vaccine.

2) To examine whether the conspiracy beliefs would prevent people from taking the COVID-19 vaccine. 


\section{Method and Data Collection}

This study adopted an online questionnaire survey. The sample population of the study captured Ghanaians who fall between the ages of 18 and 65 living in Ghana. Fifty-two out of the targeted population of 100 citizens participated in this study. The researcher collected and analysed data through Google forms. Google forms were used as a platform to create a self -prepared online questionnaire with 2 sections: Bio-data and conspiracies.

There were 10 closed-ended questions and 10 open-ended questions in all. The questionnaire was automatically hosted through a unique URL. Access to the URL link was protected by a password. A unique study ID gave participants access to the URL link to participate. The ID also ensured confidentiality of data. Responses from participants were secured using a cloud database where data was sorted, scaled, scored, and imported to excel spreadsheets.

Google forms permit online data analysis and graphical presentation. So, when participants filled the web questionnaire via social media (WhatsApp), online data was automatically recorded in Google spreadsheet in an analyzable manner which allowed for tabulation and graphical representation of data. The questionnaire responses were downloaded in excel, analysed and interpreted.

\section{Results}

\section{Objective 1}

To explore the frequency of conspiracy beliefs in Ghana after the preface of the vaccine.

Table 1. AstraZeneca vaccine in Ghana.

\begin{tabular}{ccc}
\hline $\begin{array}{c}\text { Are you happy that the drug, Oxford } \\
\text { AstraZeneca vaccine is finally available Ghana } \\
\text { to help curb the spread of the COVID 19? }\end{array}$ & Frequency & Percentage \\
\hline Yes & 40 & 76.9 \\
No & 12 & 23.1 \\
Total & 52 & 100 \\
\hline
\end{tabular}

Table 1 shows that $76.9 \%$ of which represents the majority were happy that the Oxford AstraZeneca vaccine had been secured in Ghana to help stop the spread of the virus, while $23.1 \%$ were not happy about it.

Table 2. Potency of the vaccine.

\begin{tabular}{ccc}
\hline Do you believe in the potency of this vaccine? & Frequency & Percentage \\
\hline Yes & 35 & 67.3 \\
No & 17 & 32.7 \\
Total & 52 & 100 \\
\hline
\end{tabular}


Aschwanden (2020) posits that when people are vaccinated against Coronavirus disease, the virus can not transmit as easily as possible from person to person, and the community is less likely to contract COVID-19 which is called "community immunity or "herd immunity". Studies carried out in 2020 showed that the efficacy of the AstraZeneca vaccine is $76.0 \%$ at preventing symptomatic COVID-19 beginning at 22 days following the first dose and $81.3 \%$ after the second dose (Voysey et al., 2021). Another study in Scotland found that, for symptomatic COVID-19 infection after the second dose, the vaccine is $81 \%$ effective against the Alpha variant (lineage B.1.1.7), and 61\% against the Delta variant (lineage B.1.617.2) (Sheikh, McMenamin, Taylor, \& Robertson, 2021). It is therefore not surprising to see from Table 2 that $67.3 \%$ of the respondents believe that the COVID-19 vaccine is efficacious while $32.7 \%$ said they do not believe in the potency of the vaccine.

Table 3. Intake of vaccine.

\begin{tabular}{ccc}
\hline Have you taken your jab already? & Frequency & Percentage \\
\hline Yes & 15 & 28.8 \\
No & 37 & 71.2 \\
Total & 52 & 100 \\
\hline
\end{tabular}

Table 3 highlights that $28 \%$ of the respondents had taken the vaccine already while $71.2 \%$ had not taken the vaccine. Those who had already taken the vaccine explained that their motivation was to reduce the severity of the infection and most importantly because it had been approved by the World Health Organization (WHO), the Ghana Food and Drugs Board Authority and the Ghana Health Service. However, the remaining $71.2 \%$ who had not yet been vaccinated based their hesitance on the negative rumours surrounding the vaccine and of the fact that the vaccine cannot give total protection because after one had been vaccinated, he or she must still follow the protocols that have been put in place to halt the spread.

Table 4. Vaccine population control.

\begin{tabular}{ccc}
\hline $\begin{array}{c}\text { Do you believe that the vaccine has been developed } \\
\text { to limit or control population size? }\end{array}$ & Frequency & Percentage \\
\hline Yes & 9 & 17.3 \\
No & 43 & 82.7 \\
Total & 52 & 100 \\
\hline
\end{tabular}

Previous studies identified trust as an intrinsic and potentially modifiable component of successful uptake of a COVID-19 vaccine (Abbas et al., 2018; Malik et al., 2020; Kreps et al., 2020; Lazarus et al., 2021; Wu et al., 2017). Table 4 showed that 17.3 of the respondents believed that the vaccine has not been developed to limit or control population size, while 82.7 disagreed to that asser- 
tion.

Table 5. Vaccine to usher the era of the "mark of the beast".

\begin{tabular}{ccc}
\hline $\begin{array}{c}\text { Have you ever nursed the thought that the vaccine is } \\
\text { to usher in the era of the "mark of the beast"? }\end{array}$ & Frequency & Percentage \\
\hline Yes & 7 & 13.5 \\
No & 45 & 86.5 \\
Total & 52 & 100 \\
\hline
\end{tabular}

As shown in Table 5, 13.5\% only thought that the COVID-19 vaccine is being used to launch the era of the "mark of the beast". The majority representation, 86.5, disagreed.

Table 6. Vaccine as a track device.

\begin{tabular}{ccc}
\hline $\begin{array}{c}\text { Do you believe that the vaccine contains microchip } \\
\text { or track device or it will cause infertility }\end{array}$ & Frequency & Percentage \\
\hline Yes & 5 & 9.6 \\
No & 47 & 90.4 \\
Total & 52 & 100 \\
\hline
\end{tabular}

In YouTube videos of 25 September, 2021 titled "COVID-19 vaccine" and of 29 September 2020 from India Today, it was explained how a microchip is being used to check the effect of the drugs on COVID-19. This reveals how there is still a mistrust that the microchip is what would be implanted in the human being for all its Satanic purposes, despite all clarifications on the matter (see also BBC News of 30 May, 2020). Responses from the survey (Table 6) however revealed that only $9.6 \%$ of the respondents believe the vaccine contained a track device for tracking activities of individuals as was seen in the YouTube videos, while a majority of $90.4 \%$ respondents did not agree to this assertion.

Table 7. Vaccine as a DNA falsification.

\begin{tabular}{ccc}
$\begin{array}{c}\text { Are you of the view that the vaccine will alter } \\
\text { your DNA after you take it? }\end{array}$ & Frequency & Percentage \\
\hline Yes & 5 & 9.6 \\
No & 47 & 90.4 \\
Total & 52 & 100 \\
\hline
\end{tabular}

Table 7 highlighted that $9.6 \%$ of the respondents thought that taking the COVID-19 vaccine would alter their DNA while 90.4 respondents were of the view that the coronavirus vaccine will not alter their DNA if they should vaccinate themselves. A recent article published in principia scientific.com shows Bill 
Gates admitting the COVID-19 vaccine to change the DNA, and as a result, making doctors rebel to this admission (O'Sullivan, 2020: p. 1).

Table 8. Covid-19 makers as creators of Covid-19.

\begin{tabular}{ccc}
\hline $\begin{array}{c}\text { Do you perceive that COVID-19 vaccine makers } \\
\text { created COVID-19? }\end{array}$ & Frequency & Percentage \\
\hline Yes & 14 & 26.9 \\
No & 38 & 73.1 \\
Total & 52 & 100 \\
\hline
\end{tabular}

As highlighted in Table 8, 26.9\% perceived that COVID-19 vaccine makers created COVID-19, while $73.1 \%$ whose view were contrary explained that they had read and heard that coronavirus is not created, and it is also not the first-time coronavirus had caused an epidemic globally. Their view harmonizes with Lu et al. (2020). The stated that it was not the first time that a coronavirus causing an epidemic has been a significant global health threat: in November 2019, an outbreak of coronaviruses (CoVs) with severe acute respiratory syndrome (SARS)-CoV started in the Chinese province of Guangdong and again, in September, 2012 the Middle East, respiratory syndrome (MERS)-Co V appeared.

\section{Objective 2}

To examine whether higher levels of conspiracy beliefs would prevent people from taking the COVID-19 vaccine.

Table 9. Advocates of Covid-19 vaccine.

\begin{tabular}{ccc}
\hline $\begin{array}{c}\text { If you are given the chance to convince someone } \\
\text { to take the jab, will you, do it? }\end{array}$ & Frequency & Percentage \\
\hline Yes & 34 & 65.4 \\
No & 18 & 34.6 \\
Total & 52 & 100 \\
\hline
\end{tabular}

Table 9 showed that $65.4 \%$ of the respondents were prepared to convince others to take it while $34.6 \%$ of the respondents were not ready to convince individuals to take the vaccine.

Table 10. Reasons for being an advocate of the vaccine or vice versa.

\begin{tabular}{ccc}
\hline $\begin{array}{c}\text { State your reason for agreeing or disagreeing to } \\
\text { convince people to or not to take the vaccine. }\end{array}$ & Frequency & Percentage \\
\hline Protection against virus & 34 & 65.4 \\
Right to choose/conspiracies/age & 18 & 34.6 \\
Total & 52 & 100 \\
\hline
\end{tabular}


Table 10 clearly showed that majority of the respondents (65.4) who believed in science and the potency of the vaccine to protect individuals from spreading the virus said they were prepared to convince people to take the vaccine while $34.6 \%$ responded in the negative with reasons that the vaccine is for population control, and individuals have the right to choose based on their belief or age brackets.

\section{Discussion}

Vaccination is often considered one of the most efficient means of preventing disease and is often a cost-effective tool for improving health at the population level (Bloom, 2011; Londono et al., 2021; Preaud et al., 2014). The results from data collected for this study suggested that most Ghanaians have firm belief in the potency of the coronavirus vaccine. They were convinced that Oxford/AstraZeneca that the government had acquired to be used in the country is safe because it has been approved by WHO and the Ghana Food and Drugs Board Authority, therefore it is efficacious to be used in the country. They were thus, willing to convince people who are due to various reasons like adverse health outcomes, misconceptions, lack of trust in the healthcare system, safety and efficacy, and inadequate knowledge (Setbon \& Raude, 2010) and have not yet taken the vaccine to allow themselves to be vaccinated when it is available in their communities

\section{Conclusion}

Kata (2010) posits that anti-vaccine conspiracy theories present an attempt to explain away overwhelming scientific evidence that vaccines are effective, safe, and necessary. Even though the view of Kata (2010), reinforces views of some Ghanaians in this study, most respondents believed the potency and safety of the vaccine outweigh the adverse effects which are temporary and have already taken the vaccine. They were more so willing to advocate people to vaccinate themselves when the vaccine is sent to their locality. The government of Ghana should consider intensifying education on the COVID-19 vaccine to convince more people, especially, those clouded with conspiracy beliefs about the COVID19 vaccine. This study was not without limitations. Firstly, it was mainly based on the Ghanaian context. Secondly, although it was an online survey and nationally representative, the sample size was small compared with Ghana's population.

Future studies on other variables that can also contribute to Ghanaians' intent to receive vaccines have not been considered in this study and can be researched into to address the limitation.

\section{Conflicts of Interest}

The authors declare no conflicts of interest regarding the publication of this paper. 


\section{References}

Abbas, K. M., Kang, G. J., Chen, D., Were, S. R., \& Marathe, A. (2018) Demographics, Perceptions, and Socioeconomic Factors Affecting Influenza Vaccination among Adults in the United States. PeerJ, 60, e5171. https://doi.org/10.7717/peerj.5171

Abu-Raddad, L. J., Chemaitelly, H., \& Butt, A. A. (2021). National Study Group for C-V. Effectiveness of the BNT162b2 Covid-19 Vaccine against the B.1.1.7 and B.1.351 Variants. The New England Journal of Medicine, 385, 187-189.

https://doi.org/10.1056/NEJMc2104974

Afriyie, D. K., Asare, G. A., Amponsah, S. K., \& Godman, B. (2020). COVID-19 Pandemic in Resource-Poor Countries: Challenges, Experiences and Opportunities in Ghana. The Journal of Infection in Developing Countries, 14, 838-843. https://doi.org/10.3855/jidc.12909

Asante, L. A., \& Mills, R. O. (2020). Exploring the Socio-Economic Impact of COVID-19 Pandemic in Marketplaces in Urban Ghana. Africa Spectrum, 55, 170-181. https://doi.org/10.1177/0002039720943612

Aschwanden, C. (2020). The False Promise of HERD Immunity. Nature, 587, 26-80. https://doi.org/10.1038/d41586-020-02948-4

Aylward, B., \& Liang, W. (2020). Report of the WHO-China Joint Mission on Coronavirus Disease 2019 (COVID-19).

https://www.who.int/docs/default-source/coronaviruse/who-china-joint-mission-on-c ovid-19-final-report.pdf

BBC News (2020). Coronavirus: Bill Gates "Microchip” Conspiracy Theory and Other Vaccine Claims Fact-Checked. BBC News. https://www.bbc.com/news/52847648

Bloom, D. E. (2011). The Value of Vaccination. In N. Curtis, A. Finn, \& A. Pollard (Eds.), Hot Topics in Infection and Immunity in Children VII (pp. 1-8). Springer.

https://doi.org/10.1007/978-1-4419-7185-2 1

Chen, D., Xu, W., Lei, Z., Huang, Z., Liu, J., Gao, Z., \& Peng, L. (2020). Recurrence of Positive SARS-CoV-2 RNA in COVID-19: A Case Report. International Journal of Infectious Diseases, 93, 297-299. https://doi.org/10.1016/j.ijid.2020.03.003

Chou, W.-Y. S., \& Budenz, A. (2020). Considering Emotion in COVID-19 Vaccine Communication: Addressing Vaccine Hesitancy and Fostering Vaccine Confidence. Health Communication, 35, 1718-1722. https://doi.org/10.1080/10410236.2020.1838096

Coronaviridae Study Group of the International Committee on Taxonomy of Viruses (2020). The Species Severe Acute Respiratory Syndrome-Related Coronavirus. Classifying 2019$\mathrm{nCoV}$ and Naming It SARS-CoV-2. Nature Microbiology, 5, 536-544. https://doi.org/10.1038/s41564-020-0695-Z

Dhama, K., Sharun, K., Tiwari, R., Dadar, M., Malik, Y. S., Singh, K. P., \& Chaicumpa, W. (2020). COVID-19, an Emerging Coronavirus Infection: Advances and Prospects in Designing and Developing Vaccines, Immune Therapeutics, and Therapeutics. Human Vaccines \& Immunotherapeutics, 16, 1232-1238. https://doi.org/10.1080/21645515.2020.1735227

Douglas, K. M., Sutton, R. M., \& Cichocka, A. (2017). The Psychology of Conspiracy Theories. Current Directions in Psychological Science, 26, 538-542. https://doi.org/10.1177/0963721417718261

Dror, A. A., Eisenbach, N., Taiber, S., Morozov, N. G., Mizrachi, M., Zigron, A., Srouji, S., \& Sela, E. (2020). Vaccine Hesitancy: The Next Challenge in the Fight against COVID-19. European Journal of Epidemiology, 35, 775-779. https://doi.org/10.1007/s10654-020-00671-y 
Du Toit, A. (2020). Outbreak of a Novel Coronavirus. Nature Reviews Microbiology, 18, 123. https://doi.org/10.1038/s41579-020-0332-0

Ferrara, E. (2020). What Types of COVID-19 Conspiracies Are Populated by Twitter Bots? First Monday, 25. https://doi.org/10.5210/fm.v25i6.10633

Geoghegan, S., O’Callaghan, K. P., \& Pa, O. (2020). Vaccine Safety: Myths and Misinformation. Frontiers in Microbiology, 11, 372. https://doi.org/10.3389/fmicb.2020.00372

Gruzd, A., \& Mai, P. (2020). Going Viral: How a Single Tweet Spawned a COVID-19 Conspiracy Theory on Twitter. Big Data \& Society. https://doi.org/10.1177/2053951720938405

Herek, G. M., \& Capitanio, J. P. (1994). Conspiracies, Contagion, and Compassion: Trust and Public Reactions to Aids. AIDS Education and Prevention, 6, 365-375.

Herek, G. M., \& Glunt, E. K. (1991). Aids-Related Attitudes in the United States: A Preliminary Conceptualization. The Journal of Sex Research, 28, 99-123. https://doi.org/10.1080/00224499109551597

Jolley, D., \& Douglas, K. M. (2014). The Effects of Anti-Vaccine Conspiracy Theories on Vaccination Intentions. PLOS ONE, 9, e89177. https://doi.org/10.1371/journal.pone.0089177

Kata, A. (2010). A Postmodern Pandora's Box: Anti-Vaccination Misinformation on the Internet. Vaccine, 28, 1709-1716. https://doi.org/10.1016/j.vaccine.2009.12.022

Kata, A. (2012). Anti-Vaccine Activists, Web 2.0, and the Postmodern Paradigm-An Overview of Tactics and Homilies Used Online by the Anti-Vaccination Movement. Vaccine, 30, 3778-3789. https://doi.org/10.1016/j.vaccine.2011.11.112

Kenu, E., Frimpong, J. A., \& Koram, K. A. (2020). Responding to the COVID-19 pandemic in Ghana. Ghana Medical Journal, 54, 72-73. https://doi.org/10.4314/gmj.v54i2.1

Klofstad, C. A., Uscinski, J. E., Connolly, J. M., \& West, J. P. (2019). What Drives People to Believe in Zika Conspiracy Theories? Palgrave Communications, 5, Article No. 36. https://doi.org/10.1057/s41599-019-0243-8

Kreps, S., Prasad, S., Brownstein, J. S. et al. (2020). Factors Associated with US GrownUps' Liability of Accepting COVID-19 Vaccination. JAMA Network Open, 3, e2025594. https://doi.org/10.1001/jamanetworkopen.2020.25594

Lamptey, E., Serwaa, D., \& Appiah, A. B. (2021). A Nationwide Survey of the Potential Acceptance and Determinants of COVID-19 Vaccines in Ghana. Clinical and Experimental Vaccine Research, 10, 183-190. https://doi.org/10.7774/cevr.2021.10.2.183

Lazarus, J. V., Ratzan, S. C., Palayew, A. et al. (2021). A Global Survey of Potential Acceptance of a COVID-19 Vaccine. Nature Medicine, 27, 225-228. https://doi.org/10.1038/s41591-020-1124-9

Londono, S. E., Li, X., Toor, J., de Villiers, M. J., Nayagam, S., Hallett, T. B., \& Gaythorpe, K. A. (2021). How Can the Public Health Impact of Vaccination Be Estimated? medRxiv. https://doi.org/10.1101/2021.01.08.21249378

Lone, S., \& Armad, A. (2020). COVID-19 Pandemic-An African Perspective. Emerging Microbes and Infections, 9, 1300-1308. https://doi.org/10.1080/22221751.2020.1775132

Lu, R., Zhao, X., Li, J., Niu, P., Yang, B., Wu, H., Wang, W., Song, H., Huang, B., Zhu, N. et al. (2020). Genomic Characterisation and Epidemiology of 2019 Novel Coronavirus: Implications for Virus Origins and Receptor Binding. The Lancet, 395, 565-574. https://doi.org/10.1016/S0140-6736(20)30251-8

Malik, A. A., McFadden, S. M., Elharake, J., \& Omer, S. B. (2020). Determinants of Covid-19 Vaccine Acceptance in the US. EClinicalMedicine, 26, Article ID: 100495. https://doi.org/10.1016/j.eclinm.2020.100495 
McKee, C., \& Bohannon, K. (2016). Exploring the Reasons behind Parental Refusal of Vaccines. The Journal of Pediatric Pharmacology and Therapeutics, 21, 104-109. https://doi.org/10.5863/1551-6776-21.2.104

Moore, S. (2021). The Importance of Global COVID-19 Vaccination. News-Medical. https://www.news-medical.net/health/The-Importance-of-Global-COVID-19-Vaccinat ion.aspx

O'Sullivan, J. (2020). Bill Gates Admits Covid 19 Vaccine Changes DNA, Now Doctors Rebel!

https://principia-scientific.com/bill-gates-admits-covid-vaccine-changes-dna-now-doct ors-rebel

Offit, P. A. (2010). Deadly Choices: How the Anti-Vaccine Movement Threatens Us All. Basic Books.

Oliver, J. E., \& Wood, T. J. (2014a). Medical Conspiracy Theories and Health Behaviors in the United States. JAMA Internal Medicine, 174, 817-818.

https://doi.org/10.1001/jamainternmed.2014.190

Oliver, J. E., \& Wood, T. J. (2014b). Conspiracy Theories and the Paranoid Style(s) of Mass Opinion. American Journal of Political Science, 584, 952-966.

https://doi.org/10.1111/ajps.12084

Polack, F. P., Thomas, S. J., Kitchin, N., Absalon, J., Gurtman, A., Lockhart, S. et al. (2020). Safety and Efficacy of the BNT162b2 mRNA Covid-19 Vaccine. The New England Journal of Medicine, 383, 2603-2615. https://doi.org/10.1056/NEJMoa2034577

Preaud, E., Durand, L., Macabeo, B., Farkas, N., Sloesen, B., Palache, A., \& Samson, S. I. (2014). Annual Public Health, and Economic Benefits of Seasonal Influenza Vaccination: A European Estimate. BMC Public Health, 14, Article No. 813. https://doi.org/10.1186/1471-2458-14-813

Reuters (2021). South Korea Reports More Recovered Coronavirus Patients Testing Positive Again. Reuters. https://www.reuters.com/article/us-health-coronavirus-southkorea-idUSKCN21V0JQ

Setbon, M., \& Raude, J. (2010). Factors in Vaccination Intention against the Pandemic Influenza A/H1N1. European Journal of Public Health, 20, 490-494. https://doi.org/10.1093/eurpub/ckq054

Sheikh, A., McMenamin, J., Taylor, B., \& Robertson, C. (2021). SARS-CoV-2 Delta VOC in Scotland: Demographics, Risk of Hospital Admission, and Vaccine Effectiveness. The Lancet, 397, 2461-2462. https://doi.org/10.1016/S0140-6736(21)01358-1

Sunstein, C. R., \& Vermeule, A. (2009). Conspiracy Theories: Causes and Cures. The Journal of Political Philosophy, 17, 202-227. https://doi.org/10.1111/j.1467-9760.2008.00325.x

Thigpen, C., \& Funk, C. (2020). Most Americans Anticipate a COVID-19 Vaccine within a Year, 72\% Say They Would Get Vaccinated. Pew Research Center.

Troiano, G., \& Nardi, A. (2021). Vaccine Hesitancy in the Era of COVID-19. Journal of Public Health, 194, 245-251. https://doi.org/10.1016/j.puhe.2021.02.025

Vinck, P., Pham, P. N., Bindu, K. K., Bedford, J., \& Nilles, E. J. (2019). Institutional Trust and Misinformation in the Response to the 2018-19 Ebola Outbreak in North Kivu, DR Congo: A Population-Based Survey. The Lancet Infectious Diseases, 19, 529-536. https://doi.org/10.1016/S1473-3099(19)30063-5

Voysey, M., Costa Clemens, S. A., Madhi, S. A., Weckx, L. Y, Folegatti, P. M., Aley, P. K. et al. (2021). Single-Dose Administration and the Influence of the Timing of the Booster Dose on Immunogenicity and Efficacy of ChAdOx1 nCoV-19 (AZD1222) Vaccine: A Pooled Analysis of Four Randomised Trials. The Lancet, 397, 881-891. 
https://doi.org/10.1016/S0140-6736(21)00432-3

West, H. G., \& Sanders, T. (2003). Transparency and Conspiracy: Ethnographies of Suspicion in the New World Order. Duke University Press. https://doi.org/10.2307/j.ctv11smwft

Wu, S., Su, J., Yang, P. et al. (2017). Factors Associated with the Uptake of Seasonal Influenza Vaccination in Aged and Youngish Grown-Ups a Large, Population-Grounded Check in Beijing, China. BMJ Open, 7, e017459.

https://doi.org/10.1136/bmjopen-2017-017459 